\title{
The Protection of Medical Officers in the Armed Conficts: Case Study of Indonesia
}

\author{
Mahfud \\ Faculty of Law, Universitas Syiah Kuala-Indonesia \\ mahfud.abdullah@unsyiah.ac.id
}

\begin{abstract}
International Humanitarian Law (HHI) has regulated provisions regarding the protection of medical personnel in a conflict, whether an international, non-international armed conflict or an internationalized armed conflict. These categories of various types of armed conflict are also part of the legality of the emergence of humanitarian intervention by medical personnel in an armed conflict. A form of medical care for parties who are either directly or indirectly involved in an armed conflict. In the Indonesian context, the provisions regulating separately the protection of medical personnel in armed conflict have not been regulated separately. However, considering that Indonesia has ratified the 1949 Geneva Convention, the convention can be considered as the official Indonesian national regulation on the protection of medical personnel in armed conflict. In this article, it is demonstrated that there were still many violations, especially against the purpose of war, which made medical officers and medical buildings in an armed conflict a military target, such as in the Syrian conflict, as well as domestic Indonesia such as Aceh and Papua. Several factors have led to the fall of medical personnel in various armed conflicts (both horizontal and vertical) in Indonesia, among others are: (a) The parties to an armed conflict are not aware of the provisions of the principles of international humanitarian law. (b) The parties are suspicious of the neutrality of the medical personnel, as well as (c) Not having a good communication system between the conflicting parties and medical personnel.
\end{abstract}


Keywords: International humanitarian law; Armed Conflict; Medical Officer.

\section{A. Introduction}

War is a common phenomenon of humans. Since there have been creatures in this world, he has never been free from the problems of war. In its broadest sense, war is violent contact between two similar but different parties. ${ }^{1}$ As a consequence, war causes damage and death with various characteristics of war itself. ${ }^{2}$ In such conditions, killing each other between humans is a legal act. These requirements are contained in the law of war or International Humanitarian Law (IHL) as part of international law. ${ }^{3}$

Identify IHL appears when a military attack as an opener arises between countries or territories of the sovereignty of a region. ${ }^{4}$ This can be seen in the history of the law of war itself as has been proclaimed by most of the great civilizations of humanity. ${ }^{5}$ Likewise, IHL forms most of the international public law and consists of regulations which during times of armed conflict aim to resolve problems related to humanity as a result of armed conflict, both international and non-international. ${ }^{6}$

The main objective of the humanitarian IHL is also defined in the definition of IHL, one of which regulates the treatment of individuals during armed conflicts ${ }^{7}$ and limits areas and parties that can

1 Suryohadiprojo, Sayidiman. Pengantar Ilmu Perang, Pustaka Intermasa, Jakarta, 2008, p. 1-2.

2 Small, Melvin and Singer, David J. International War An Anthology and Study Guide, Dorsey Press Homewood, IL, USA, 1985, p. 5.

3 Khadduri, Majid. War and Peace in The Law of Islam (Perang dan Damai dalam Hukum Islam), Tarawang Press, Jakarta, 2002, p. 47.

4 Small, Melvin, and Singer, J. David. Patterns In International Warfare, 18161980, dalam International War An Anthology And Study War, Dersey Press, HOMEWOOD, IL, USA, 1985, p. 17.

5 Wright, Quincy. Hukum Humaniter Sebelum Dikodifikasi, Bulletin ICRC, 2004, p. 9.

6 Buletin ICRC, Hukum Humaniter Internasional, Menjawab PertanyaanPertanyaan Anda, ICRC, 2004, p. 4.

7 Rudy, T. May. Hukum Internasional 2, Refika Aditama, Bandung, 2001, p. 
be used as legitimate military targets. The definitions of some of the restrictions and terms of war crimes are carried out to humanize war with all its limitations. ${ }^{8} \mathrm{~A}$ number of these limitations arise because in general an armed conflict often ignores human values. ${ }^{9}$ Violation of these restrictions can be considered as an offense in the form of international crimes or international torts (international delinquencies).$^{10}$ Crimes committed during war or at least related to war events, are known as war crimes. ${ }^{11}$

One of these restrictions is the prohibition of parties involved in an armed conflict not to subject medical personnel to military attacks. Regulations regarding the protection of medical teams in an armed conflict are also a customary practice, which is known as customary IHL. ${ }^{12}$ Thus humanitarian law is aimed at "protecting certain categories of people who do not or are no longer participating in combat or those who are involved in humanitarian missions, in this case medical personnel and to limit the means and methods of fighting. ${ }^{13}$

In the HHI provisions, the discussion of armed conflict can be addressed in various types of armed conflict itself. The provisions

78.

8 Wagiman, Wahyu. Hukum Humaniter Dan Hak Asasi Manusia, Seri Bahan Bacaan Kursus HAM untuk Pengacara X, Tahun 2005, makalah seminar yang diadakan oleh ELSAM (Lembaga Studi dan Advokasi Masyarakat) Jakarta, p. 7.

9 Lachs, Manfred, and Swinarski, Cristophe. Responsibility For The Development of Humanitarian Law, Studies and Essay on International Humanitarian Law and Red Cross Principles, Martinus Nijhoff Publishers, Leiden, 1984, p. 397.

10 Atmasasmita, Romli. Pengantar Hukum Pidana Internasional, Refika Aditama, Bandung, 2000, p. 11.

11 Syahrizal, Irwan. Pengaturan Pelanggaran Berat Dalam Hukum Humaniter dan Penerapan Hukumnya di Indonesia, Tesis, Universitas Padjadjaran, Bandung, 2003, p. 93-94.

12 Henckaerts, Jean Marie. "Studi (Kajian) tentang Hukum Humaniter Internasional Kebiasaan”, Jurnal Internasional Review of The Red Cross, Volume 87, No. 857, Maret 2005

13 Kalshoven, Frits dan Zegveld, Liesbeth. Constraints on the Waging of War: An Introduction to International Humanitarian Law, ICRC, Geneva. 2001, p. 12-14. 
regarding this type of armed conflict can be in the form of international, non-international armed conflicts or internationalized armed conflicts. ${ }^{14}$ The scope of its legal application, the Geneva Conventions of 1949, comprises rules of law covering almost all aspects of modern armed disputes. ${ }^{15}$ The Convention applies to all events of war which may arise between two or more signatory parties, even if the state of war is not recognized by one of them. ${ }^{16}$

In the dynamics of armed conflict itself, the dichotomy of armed conflict is also distorted in two dichotomies, namely war and armed conflict. The provisions regarding war are the terminology of armed conflict in the sense that the conflicting parties have met the qualifications as an armed group, be it belligerence or irsugence and are oriented as a political movement. The provisions regarding these groups in the conflict in Indonesia can be observed in the armed conflicts of Aceh and Papua. Meanwhile, the provisions concerning other armed conflicts are armed conflicts which are moved by certain groups without political motives. ${ }^{17}$ An example of this conflict can be seen in the Ambon horizontal conflict. The categories of various types of armed conflict are also part of the legality of the emergence of humanitarian intervention that arises from various armed conflicts themselves. One of the legality of such humanitarian intervention is medical assistance for parties who are directly or indirectly involved in an armed conflict. In its operation, the 1949 Geneva Convention regulates separately the protection of medical personnel in conflict areas. This provision is contained in Article 24 Chapter IV of the 1949 Geneva Convention. ${ }^{18}$ Respect and protection for medical

14 Permana Sari, Arlina, et.al, Pengantar Hukum Humaniter, ICRC, Jakarta, 1999, p. 139.

15 Rizki, Rudi M. Pokok-Pokok Hukum Hak Asasi Manusia Internasional, Seri Bahan Bacaan Kursus HAM untuk Pengacara X Tahun 2005, Materi : Hukum HAM Internasional, Lembaga Studi dan Advokasi Masyarakat, Elsam, Jakarta, 2005, p. 6.

16 Kusumaatmadja, Mochtar. Konvensi-Konvensi Palang Merah 1949, Bina Cipta, Bandung, 1986, p. 18-19.

17 Istanto, Sugeng F, Hukum Internasional, Universitas Atma Jaya, Yogyakarta, 1994, p. 104.

18 Article 24 Chapter IV of the 1949 Geneva Convention which states that; 
personnel in a conflict is not only in the form of prohibition against medical personnel but also for health buildings designated for humanitarian tasks in an armed conflict. This provision can be clearly seen in the provisions of Article 19 Chapter III of the 1949 Geneva Convention. ${ }^{19}$

The application of the provisions of these Articles implies clearly that the Geneva Conventions of 1949 provide clear and unequivocal protection when violations of the provisions set out in the convention concerning the scope of the subjects concerned. as well as objects protected in the provisions of this Convention are violated both for the protection of the injured and sick. Including respect and protection of medical and religious personnel, guarding and protection of medical units, medical buildings and transportation as well as special protection for distinctive symbols which must be protected, the provisions of this convention must be applied in an armed conflict.

In the Indonesian context, the provisions of the protection of medical personnel in armed conflict have not been regulated separately. However, considering that Indonesia has ratified the $1949 \mathrm{Ge}-$ neva Convention, this convention can be considered as the official Indonesian national regulation on the protection of medical personnel in armed conflict. This is reasonable because Indonesia has become a party to the Geneva Conventions of 1949. Indonesia's self-binding

"Members of the health service specially employed to seek or collect, transport or care for the wounded and sick, or to prevent disease, and staff who are specially employed in the administration of medical units and buildings, as well as clergy who serve in the armed forces, must be respected and protected in all circumstances".

19 Article 19 Chapter III of the 1949 Geneva Convention which explicitly states : "Fixed establishments and mobile medical units of the Medical Service may in no circumstances be attacked, but shall at all times be respected and protected by the Parties to the conflict. Should they fall into the hands of the adverse Party, their personnel shall be free to pursue their duties, as long as the capturing Power has not itself ensured the necessary care of the wounded and sick found in such establishments and units. The responsible authorities shall ensure that the said medical establishments and units are, as far as possible, situated in such a manner that attacks against military objectives cannot imperil their safety". 
has been manifested by the issuance of Law no. 59 of 1958 concerning the Participation of the Republic of Indonesia in All Geneva Conferences on 12 August 1949. Given that the ratification of the Geneva Conventions has been carried out by issuing Law No. 59 of 1958, the provisions of the Geneva Convention are also binding as is the case with laws in general in Indonesia. So, it can be said that the special regulation in Indonesia and the international world which regulates the protection of health workers in the battlefield is the Geneva Convention. ${ }^{20}$

Nevertheless, in reality, there are still many violations, especially against the purpose of war, which make medical officers and medical buildings in an armed conflict military targets. This can be seen in various armed conflicts that have occurred in various parts of the world such as in the Syrian conflict, as well as in domestic Indonesia such as Aceh and Papua. In the Syrian conflict, the death of doctor Muhammad Abyad, who worked at the hospital run by MSF in Aleppo province to provide care for conflict victims. His death is a deep loss for his family, the patients he cares for, and for MSF The MSF team is made up of international and Syrian staff who run six hospitals and four health centers in northern Syria. ${ }^{21}$

The same is true in several national armed conflicts. The Aceh and Papua conflict cases are an example. In the case of the death of $\mathrm{dr}$. Fauziah 4 December 2013 in the Gampong Cot Kruet area, Peudada District, North Aceh Regency (now Bireuen Regency). The bloody incident began with information about the shooting in Gampong Alue Kuta, Peudada District, which sacrificed residents. Based on this report, the Mass Riot Fighting Force (PPRM) based in Bireuen City was sent to support the sub-district team that would identify bodies and conducts research at the Crime Scene. The team also included a medical team consisting of the head of the Peudada Puskesmas, Dr. Fauziah, along with four nurses who would assist with post mortem

20 http: / / www.hukumonline.com/klinik/detail/cl651/perlindungan-hukum-bagi-tim-medis-di-wilayah-konflik.

21 http:/ / www.tribunnews.com/internasional/2013/09/05/dokter-bedahmsf-ditemukan-tewas-di-aleppo-suriah 
et repertum for the bodies of the shooting victims who had been lying rigidly on the transmigration area of Alue Kuta. The troop truck arrived at Gampong Cot Kruet, Peudada District, or a few kilometers from the Crime Scene. Suddenly, the truck was hit by a group of armed people. They were showering gunfire from above the hill behind the bush. The consecutive shots hit dr. Fauziah's body. ${ }^{22}$

In the Papua separatist conflict, the Shooting Case of PMI Doctors took place in Puncak Senyum, Puncak Jaya Regency, Papua and targeted the Indonesian Red Cross (PMI) ambulance by commtted by an unknown person (OTK) on Wednesday, July 31, 2013. The shooting was targeting an ambulance carrying the sick. A doctor with the initials AY was pronounced dead in the unlucky incident, while three others were injured to the cheek, arm, and right rib. ${ }^{23}$

A series of cases that the author presents, seems to have shown that, how the neglect of humanitarian values for a doctor or medical officer in an armed conflict still occurs, even though international humanitarian law has regulated it separately that medical officers are also parties. who also get special protection in an armed conflict. Therefore, in the main part of writing this article, we will discuss the provisions of humanitarian law regulating the protection of medical personnel in an armed conflict and what factors cause frequent actions that make medical officers the target of military attacks in an armed conflict.

\section{B. Result and Discussion}

\section{Humanitarian Law Provisions Concerning the Protection of Medical Officers in an Armed Conflict}

Provisions regarding the binding of IHL within the national scope of a country in the normative regulations of IHL can be found in

22 Syamsudin, Otto Ishak dan Yakob, Abdul Rahman. Catatan Pristiwa Kekerasan di Aceh Sepanjang Tahun 1999, (Menjaring Hari Tampa Air Mata), Koalisi NGO HAM Aceh, Banda Aceh, 2000, p. 67.

23 http:// nasional.kompas.com/read/2013/08/05/1452008/ JK.Penembakan.Dokter.PMI.di.Papua.Langgar.Hukum.Internasional 
their entirety in the four 1949 Geneva conventions. All of the four IHL conventions imply an obligation for parties involved in an armed conflict to respect the provisions of the implementation of war in a true manner jus bellum and jus in bello. This is as stipulated in Articles 1 and 2 of the 1949 Geneva Convention which states: Article 1 "The High Contracting Parties undertake to respect and guarantee respect in all circumstances". Meanwhile, Article 2 regarding the entry into force of the convention states in paragraph 1 that: "... This Convention shall apply to all declared war events or any other armed conflict which may arise between two or more signatories, even if a state of war is not recognized by one of them ". ${ }^{24}$

From the provisions of the article above, it can be concluded that there is legitimacy that this provision of humanitarian law applies to every armed conflict, thus giving rise to the responsibility of both the state and individuals to be responsible for all serious violations of any provisions of the convention. It is also the basis of this Article that can be used as justification for asking the parties involved in an armed conflict to provide protection to medical officers who are carrying out their mission in an armed conflict.

Provisions regarding the protection of media officers on the battlefield are regulated and codified separately in Chapter III and Chapter IV of the 1949 Geneva Convention. Substantively the duties and activities of medical officers are impartial, neutral, and independent, whose mission is a mere humanitarian mission, namely protecting the lives and dignity of victims of war and victims of internal violence and providing them with assistance. Medical personnel also seek to prevent suffering by promoting and strengthening international humanitarian law and universal humanitarian principles.

The noble provisions of the spirit of humanity can be seen in the various provisions of the Geneva convention of 1949. The provisions of this article can be seen in the provisions of Article 4 of the 1949 Geneva Convention. ${ }^{25}$ The provisions of Article 10 illustrate

24 See Article 1 and 2 of Geneva Convention 1949, also Kusumaatmadja, Mochtar, Op.Cit, p. 18-19.

25 Article 10 Chapter IV of the 1949 Geneva Convention states that; "The 
that there is an obligation to protect all parties to medical personnel in an armed conflict and to carry out acts of respect for those who must be protected. This is also as mandated by Article 19 of the 1949 Geneva Convention. ${ }^{26}$

The provisions of these articles indicate how strong the obligations that must be carried out by the parties involved in an armed conflict to provide protection both to medical or health premises and to medical personnel who are carrying out their mission in an armed conflict. These humanitarian spirits also emerge because of the essential obligation of the basic rules of international humanitarian law to protect humans in situations of violence. These basic rules are a small but central and essential part of international human rights law.

The provisions for the protection of medical personnel in an armed conflict can be seen in Articles 25 and 26, Chapter IV of the Geneva Conventions in 1949. ${ }^{27}$ Both Articles have given a clear signal that the parties to an armed conflict must respect and provide protection for medical personnel in an armed conflict. The two articles provide the criteria for several groups of people to be respected and

High Contracting Parties may at any time agree to entrust to an organization which offers all guarantees of impartiality and efficacy the duties incumbent on the Protecting Powers by the present Convention.

26 Article 19 Chapter IV of the 1949 Geneva Convention states that; "Fixed establishments and mobile medical units of the Medical Service may in no circumstances be attacked, but shall at all times be respected and protected by the Parties to the conflict. Should they fall into the hands of the adverse Party, their personnel shall be free to pursue their duties, as long as the capturing Power has not itself ensured the necessary care of the wounded and sick found in such establishments and units. The responsible authorities shall ensure that the said medical establishments and units are, as far as possible, situated in such a manner that attacks against military objectives cannot imperil their safety".

27 Article 25 Chapter IV of the 1949 Geneva Convention states that: " Members of the armed forces specially trained for employment, should the need arise, as hospital orderlies, nurses or auxiliary stretcher-bearers, in the search for or the collection, transport or treatment of the wounded and sick shall likewise be respected and protected if they are carrying out these duties at the time when they come into contact with the enemy or fall into his hands". 
protected in case of armed conflict.

Medical officers in the perspective of international humanitarian law are classified as a non-combatant group which is another auxiliary organization apart from kepalangmerahan activities. The medical personnel's humanist expansion extends to the provision of assistance that can be provided to prisoners and prisoners of war in the occupied territories. Organizationally, the 1949 Geneva Convention contains the activities of these medical officers in detail with the concentration of activities:

1. Humane treatment and respect for wounded and sick members of the war without causing harm (See Article 12)

2. To classify the groups of people who are wounded and sick in an armed conflict (see Article 13).

3. The confirmation of prisoners of war, which is specified by international law concerning prisoners of war specifically (see Article 14) concerning.

4. Provisions regarding the obligations of the parties to the dispute to seek and collect the wounded and sick (see Article 15).

5. The parties to the dispute must record as soon as possible any person injured, sick, or dead by the opposing party (see Article 16).

6. Obligation to guarantee the body must be buried with respect (Article 17).

7. Obligations to provide physical and spiritual care to the wounded and sick (see Article 18). ${ }^{28}$

In addition to these organizational obligations, the 1949 Geneva Conventions also contain the obligation to protect special non-military organizations aimed at helping the lives of civilians. Where the obligation is also borne by the medical officer or the equivalent for him. Such as the administration of a medical unit or the operation and administration of medical transport, these assignments can be permanent or temporary. ${ }^{29}$ As for what is meant by medical officers

28 See the articles concerning the issue.

29 Kushartoyo, Ketentuan-Ketentuan Lemabaga palang Merah Dalam Hukum Humaniter, Hukum Humanity, published on celberation of the 50 Year of the 
or their equivalent, the clear regulation can be seen in Article 8 Letter (c) Additional Protocol to the Geneva Convention I of 1977 which was developed into a civil defense organization. ${ }^{30}$

The emergence of a number of these regulations seems to clarify the humanist position of international humanitarian law in an armed conflict. Whereas in fact, a humanitarian intervention involving medical personnel in an armed conflict aims to stop the abusive treatment of combatants and those who are not involved in an armed conflict, both international, non-international armed conflicts and internationalized armed conflicts. More specifically, a brutal and large-scale treatment that is contrary to the beliefs of the peoples of the nations.

The most important differentiating factor from the qualification of the types of armed conflict, be it international, non-international or internationalized armed conflict, can be seen from the legal status of the parties to the dispute. In an international armed conflict, both parties have the same legal status, as both are states. As for noninternational armed conflicts, the status of the two parties is not the same, one party has the status of a state, while the other party is a non-state entity. Meanwhile, the internationalization of the conflict itself is the entry of one of the parties, in this case the state, to sup-

Geneva Convention 1949 (Jeneva Conventions 1949), Pusat Studi hukum Humaniter Fakultas hukum Universitas Trisakti, Jakarta, 1999, p. 52.

30 As for what is meant by medical officers or their equivalent as stipulated in the provisions of Article 8 Letter (c) defines (c) ; "medical personnel" means those persons assigned, by a Party to the conflict, exclusively to the medical purposes enumerated under subparagraph (e) or to the administration of medical units or the operation or administration of medical transports. Such assignments may be either permanent or temporary. The term includes:

i) medical personnel of a Party to the conflict, whether military or civilian, including those described in the First and Second Conventions, and those assigned to civil defense organizations;

ii) medical personnel of national Red Cross (Red Crescent, Red Lion, and Sun) Societies and other national voluntary aid societies duly recognized and authorized by a Party to the conflict;

(iii)medical personnel of medical units or medical transports described in Article 9, paragraph 2;". 
port organized armed groups (rebels) or between armed groups with one another. ${ }^{31}$

Especially for armed conflict that occurred in Aceh and Papua, the qualification of armed conflict is included in the qualification of non-international armed conflict. The provisions on non-international armed conflict in the HHI regulation can be seen in Article 1 paragraph (1) Additional Protocol II 1977. ${ }^{32}$ The main substance of the emergence of arrangements for the types of armed conflict in HHI regulations is actually inseparable from the characteristics of war itself. as part of violence between parties involved in an armed conflict strives to achieve the final outcome of war, namely the victory of war on the part of the enemy. But on the other hand, the formulation of efforts to win the war by the parties involved in an armed conflict is also limited by various codes of behavior in war. Both fellow combatants and those who are not part of the conflict but are humanitarian actors who must also be kept away from military targets such as medical officers who are involved in an armed conflict. $^{33}$

However, even though several regulations of the 1949 Geneva Convention have specifically contained the obligation of combatants to provide special protection to medical personnel, violations of a number of these regulations still occur, even recurring and recurring

31 Haryomataram, "Uraian Singkat Tentang Armed Conflict," Paper presented at the Seminar of International Humanitarian Law and Human Rights, Banda Aceh, 1999, p. 3.

32 Article 1 paragraph (1) Additional Protocol II 1977 states: "This Protocol, which develops and supplements Article 3 common to the Geneva Conventions of 12 August 1949 without modifying its existing conditions of application, shall apply to all armed conflicts which are not covered by Article 1 of the Protocol Additional to the Geneva Conventions of 12 August 1949, and relating to the Protection of Victims of International Armed Conflicts (Protocol I) and which take place in the territory of a High Contracting Party between its armed forces and dissident armed forces or other organized armed groups which, under responsible command, exercise such control over a part of its territory as to enable them to carry out sustained and concerted military operations and to implement this Protocol."

33 R, Kosirnik , "The 1977 Protocol ; A Landmark In The Development of International Humanitarian Law,” ICRC, Oktober, 1997 p. 7. 
in an armed conflict. The situation is very worrying and it seems as if there is something missing link from a number of these humanitarian regulations that are often outlawed. This is even though the medical intervention of medical personnel in an armed conflict is urgently needed. Their involvement does not reveal their interference in war and political affairs but purely humanitarian reasons arising from the excess of the war.

\section{Factors That Cause Victims of Medical Officers in an Armed Conflict}

The provisions of international humanitarian law regulating the protection of medical personnel do not only attach medical individuals who are carrying out their mission in an armed conflict but also concern with the protection to medical facilities/health buildings, as stipulated in the Article 19 of the 1949 Geneva Convention. The provisions regarding the obligation to protect medical personnel in an armed conflict are closely related to the legal status of the organization where the medical personnel is located. This can be seen in the ICRC organization.

As a neutral organization, the existence of the ICRC is seen as an organization that has immunity rights and privileges as regulated in diplomatic law. Several privileges and immunities in the form of immunity from due process, which protects him from administrative and court hearings and the inviolability of the ICRC archives and documents.

In carrying out its activities in conflict areas the ICRC consults and cooperates with international and non-governmental organizations operating in the same context while maintaining its independence. The main areas of cooperation between the ICRC and national associations include:

1. Provision of technical expertise and material and financial assistance to national associations to help them develop their skills, structures, and working relationships so that they can carry out their duties and responsibilities effectively and efficiently; 
2. Advise and support national associations regarding compliance with the requirements for recognition as a red cross or red crescent association, on the adoption and revision of their basic budget, and other legal matters, in particular, relating to the implementation of humanitarian law or compliance with these laws.

3. Increased operational information exchange and increased coordination of activities among the components of the international red cross and red crescent activities to make the best use of available resources and help strengthen mutual support between them on behalf of victims of armed conflict and situations of violence domestically and on behalf of the recipients of aid following the Seville agreement. ${ }^{34}$

Provisions regarding the protection of medical personnel in their operational activities in a continuous conflict, in the scope of Indonesian national regulations, can be seen in the Decree of the Minister of Health of the Republic of Indonesia NUMBER: 14/Menkes/SK/ I/ 2002 concerning Guidelines for Handling Health Problems Due to Complex Emergencies. In the context of protecting medical personnel, humanitarian interventions have emerged by medical personnel due to medical emergencies that require immediate treatment, where the qualifications of these conditions are explained separately.

Provisions regarding the protection of medical personnel in their operational activities in a continuous conflict, in the scope of Indone-

34 The Seville Agreement is an arrangement on relations between fellow national associations of the national red cross / red crescent. The responsibilities of each component of the movement are further detailed in the Seville agreement, which was adopted by the council of delegates in 1997 . The Seville Agreement gave the ICRC a leading role for international operations carried out by national associations in armed conflict, including operations concerning internal refugees. The ICRC is responsible for checking whether a national association to be formed meets the criteria to become a member of the movement and can work under the basic principles of the movement. If he does, the ICRC will give official recognition to the international federation. However, such applications are jointly examined by the ICRC and Federasai International. See, Kenali ICRC, September 2006, p. 10 and $46-47$. 
sian national regulations, can be seen in the Decree of the Minister of Health of the Republic of Indonesia NUMBER: 14 / Menkes/SK/ I/ 2002 concerning Guidelines for Handling Health Problems Due to Complex Emergencies. In the context of protecting medical personnel, humanitarian interventions have emerged by medical personnel due to medical emergencies that require immediate treatment, where the qualifications of these conditions are explained separately.

Decree of the Minister of Health of the Republic of Indonesia NUMBER: 14 / Menkes/SK/I/2002 concerning Guidelines for Handling Health Problems as a Result of Complex Emergencies qualifies the emergency with limits and definitions on six (6) qualifications of understanding including:

a. Complex Emergencies

A complex emergency is an emergency characterized by disturbances and threats to the population as well as humanitarian and logistical assistance. The main cause of this emergency was political instability which was exacerbated by the continuous disturbance of security and public order (kantibmas). Characteristics or characteristics of complex emergencies are instability and malfunctioning of public services as well as disruption of communication systems (telephone, fax, medical radio, internet, etc.); partial and or complete loss of administrative control, inability to protect civilians, inability to provide primary public services, violent conflict resulting in death, physical trauma and psychosocial disorders and disabilities; often accompanied by genocide or genocide, sexual violence, and mutilation.

b. Impact of Complex Emergencies on Public Health Aspects

Complex emergencies result in increased morbidity and mortality, population displacement, mass concentration/refugees, lack of food supplies, and the potential for outbreaks of infectious diseases due to decreased nutritional status and disruption of vector eradication, disrupted clean water supplies, poor environmental sanitation, paralyzed health services, Post Traumatic Stress (PTS), especially in children and women, the polarization of health services, the large number of health workers leaving 
the place, disruption of victim evacuation and communication between officers.

c. Civil order is the level of the community situated in an area in the safe category. The control committee is at the Police. Conditions of Civil Order can be distinguished: (i) Safe; Community activities are running normally, no incident has surfaced, (ii) Swamp; Some community activities have begun to be disrupted due to limited security disruption, (iii) Bad; Most of the community's activities have been disrupted, there are victims including injuries, death, and property loss.

d. Civil Emergency is the level of the community situation in an area which is no longer able to be controlled by the police so that the security control command is under the Civil Authority after being declared by the competent official (president).

e. Military Emergency is a level of community situation in a more severe condition so that the command for security control is transferred to the Military Authority after being declared by the competent official (President).

f. Chaos is the situation and condition of the community in an area or several areas in the form of Civil Order status, Civil Emergency and Military Emergency which is colored by the chaotic atmosphere in almost all regions can be in the form of anarchist activities, mass brutality, vandalism, looting and acts of lawlessness, where the legal provisions have not been obeyed by the masses, while the authorities receive an extraordinary burden to overcome. ${ }^{35}$

Overcoming health problems due to complex emergencies as mentioned above in its operational implementation requires integration and cooperation with cross-programs and cross-sectors. For this reason, a guideline is needed as a reference for implementing complex emergency response activities in Provinces and Regencies / Cit-

35 The Provisions (B) about the Limitation and the Definition in the Decree of the Ministry of Health of the Republic of Indonesia No: 14/Menkes/ SK/I/2002 Concerning the Guidlines for Handling Health Problems Due To Complex Emegergency. 
ies following regional specificities. The cross-program includes how to protect medical officers who are serving in a conflict who have the qualifications as described in the above definition. These provisions can be seen in the rescue, emergency response, and rehabilitation efforts which include:

a. Evacuate victims both those involved in violent conflict and those only affected to a safe place.

b. Security and taking preventive measures to rescue injured victims, and so on.

c. Coordinate and mobilize existing resources belonging to both the Government and the community to accommodate and distribute aid in an emergency. ${ }^{36}$

Provisions regarding security and taking preventive measures to rescue injured victims, etc., as regulated in letter (b) above, in the implementation of security and preventive tasks are carried out by the state security apparatus in this case the TNI/POLRI. As a security institution, the main duties and functions of the TNI/POLRI are only as security assistants for medical officers who are assigned to an armed conflict.

The obligation to obey parties involved in an armed conflict, especially medical officers in an armed conflict, even though it is covered by several norms both contained in the convention and its additional protocols, still occur violations. The violation in the form of falling victims of medical personnel in an armed conflict seems to reinforce the statement that something is missing from the parties involved in an armed conflict in understanding the contextual provisions of international humanitarian law. This can be seen in several armed conflicts that occurred in several regions in Indonesia. This context is inseparable from a legal understanding of the characteristics of armed conflict with the qualifications and typology of conflict

36 The Provisions on the Management of Countermeasures of Refugess, the Decree of the Ministry of Health of the Republic of Indonesia, the Decree of the Ministry of Health of the Republic of Indonesia RI No: 14/Menkes/ SK/I/2002 Concerning the Guidlines of Handling for Health Problems Due To Complex Emegergency. 


\section{Mahfud}

and has a very significant influence on the questions and answers to why there are still victims of these medical officers. The characteristics of the armed conflict that occurred in Indonesia can be divided into two major groups:

1. Horizontal conflict

In context, horizontal conflict is a conflict that occurs between communities that are triggered by a slight tendency, be it the nuances of ethnicity, ethnicity, religion, social strata, the political orientation of a social group that causes acts of violence and vandals. Conflicts that characterize the aforementioned acts of vandalism can be seen and occurred in conflicts in Kalimantan (between ethnic Madurese, Malay, and Dayak), in Ambon, Poso, and Maluku (migrants, natives, Muslims, Christians, clients of the political elite), social and ethnic riots in May 1998 in Jakarta, as well as the massacre of PKI activists in 1966.

2. Vertical conflict

Vertical conflict is a conflict that occurs between a social group and the social axis. In the terminology of humanitarian law, the understanding of vertical conflict arises in armed conflict which is separatism in nature. The tendency of this conflict can be seen in the cases of Aceh and Papua.

The emergence of qualification of the two types of conflict has a very close relationship with the obligation for parties to an armed conflict to protect medical personnel. The nature and characteristics of the two types of conflict mentioned above in the development of several armed conflicts that have occurred and are currently occurring in Indonesia, provide identification of why medical personnels are vurnerable to victims.

The emergence of humanitarian intervention by medical personnel in an armed conflict is inseparable from the effects of armed conflict which causes a health crisis such as victims of injury or death or the evacuation of residents from the conflict area. All of these situations require immediate health care. However, in the process of its activities, it is not uncommon for medical personnel to become victims. In general, from the findings of field research, several factors 
have led to the fall of several medical personnel victims in various armed conflicts (both horizontal and vertical) in Indonesia, among others, because:

a. The parties to an armed conflict are not aware of the provisions of the principles of international humanitarian law.

The qualification of the conflict can be seen in the type of conflict that has a separatist dimension. Examples of cases of armed conflict that occurred in Aceh and Papua. In both cases of separatism (Aceh and Papua), the backgrounds of combatants consist of those with very low educational qualifications. Many of them do not receive higher education. So it is difficult to ask them to comply with the signs of humanitarian law that are internationally strong in conflict activities.

In the case of Papuan separatism, the majority of the members of the OPM (Free Papua Organization) combatants come from among those who are not highly educated. Almost all OPM combatants who are scattered in mountainous areas have not received a basic education at all. Many of them cannot read and write or are illiterate and what is worse, many of them cannot speak the national language, in this case, the Indonesian language.

Their involvement in the conflict to become OPM combatants was inseparable from customary decisions or customary leaders to fight against the NKRI government (the Unitary State of the Republic of Indonesia). On the other hand, Papua's terrain conditions are tough and very difficult to trace because there is no road access and the only access is air transportation. Seeing the nature and characteristics of the combatants' educational level along with their various backgrounds involved in the conflict, it is very difficult to be able to ask these combatants to understand the signs of humanitarian law in general.

Another fact that causes the emergence of victims of medical personnel in the Papuan armed conflict is inseparable from the absence of socialization from the local Muspida regarding general principles of humanitarian law, especially regarding the 
neutrality of medical personnel who carry out their missions in the field. Socialization of the prohibition for parties involved in armed conflict not to target medical personnel in armed contact. This situation arises because of the pockets of the operation of the OPM, which are included in the scope of the newly created districts in the assessment structure of an area which is not feasible to be split into a Regency. This condition was exacerbated by the absence of Muspida elements in place. This situation had an impact on the disappearance of the civilian medical officers who served in the operational areas of the OPM. In addition to the absence of security guarantees, the medical officers on duty (remote/remote areas) are a high cost of living and the absence of infrastructure, transportation, and security.

b. The parties were suspicious of the neutrality of medical personnel.

The emergence of suspicion from the warring parties which caused medical personnel to fall apart was inseparable from the method of war used by the military. As a method of war, the military is said to often use the attributes of medical symbols such as the international red cross. As a means of gathering information, the security forces often use medical transportation such as ambulances to gather intelligence data to identify pockets of concentration of opposing combatants or guerrillas.

These indications have resulted in a loss of confidence in the neutrality of medical officers who are carrying out their activities in the field. Separatists could no longer distinguish neutrality from the symbol between military medics and the PMI symbol and took a stand to attack these medics. The attack was triggered by a deep suspicion from the separatist party with the assumption that the soldiers could be carrying out espionage activities to find out and arrest several OPM leaders who were on the wanted list by the TNI and Polri.

c. The lack of a good communication system between the conflicting parties and medical personnel.

Separatism conflict in the sense that it occurs in a country 
and one of the parties involved in the conflict has not been recognized as one of the objects of international law (belligerence/insurrection). The pattern of handling the conflict is still structured around a criminal approach pattern. The approach means that the parties are not treated as combatants and receive the protection as stipulated in international humanitarian law.

This can be seen in conflicts such as Papua separatism. In the Papua conflict, the emergence of victims of medical officers was inseparable from the lack of good communication between the medical parties and the OPM separatist group. The absence of such communication channels is also inseparable from the government's attitude to close the internationalization faucet of the Papua conflict. On the other hand, it is difficult for PMI volunteers to meet and communicate with OPM separatist members to explain the reasons for the performance of PMI's operational activities in the Papua conflict.

The only communication that PMI can do when evacuating conflict victims of Papua's separatism is only with the security forces. Not infrequently, sometimes to prevent victims of medical officers from carrying out their actions, these officers are provided with escort assistance from security forces. However, this act of escorting backfired on the medics because they were eventually considered to be in cahoots with the security forces and were considered legitimate targets militarily.

\section{Conclusion}

The obligation to protect medical personnel in historical armed conflicts can be referred to in the 1864 Geneva Conventions which are intended to protect medical personnel and hospitals and require the shelter and care of wounded and sick combatants. The premise of this convention is that ambulances and hospitals must be treated as neutral parties and their existence must be respected. Medical and hospital personnel cannot be targeted for attack and prisoners of war, wounded and sick troops must be assembled and treated, and 
personnel, ambulances, and hospitals should display a red cross sign over a white base. Protection of medical personnel as well as medical organizations is sometimes given immunity and privileges so that this person can work neutrally and independently. The factors that have led to the fall of several victims of medical personnel in various armed conflicts (both horizontal and vertical) in Indonesia, include: (a). The parties to an armed conflict are not aware of the provisions of the principles of international humanitarian law, (b). The parties are suspicious of the neutrality of medical personnel, (c). The lack of a good communication system between the conflicting parties and medical personnel.

\section{Bibliography}

\section{Conventions and Legal Documents}

Genewa Convention, 1949.

Keputusan Menteri Kesehatan RI NOMOR : 14/Menkes/SK/I/2002

Tentang Pedoman Penanggulangan Masalah Kesehatan Akibat Kedaruratan Kompleks.

The Decree of the Ministry of Health of the Republic of Indonesia No: 14/Menkes / SK/I/ 2002 Concerning the Guidlines of Countermasures of Health Problems Due To Complext Emegergency.

\section{Book/Journals}

Atmasasmita, Romli. 2000. Pengantar Hukum Pidana Internasional, Refika Aditama, Bandung.

Buletin ICRC, Hukum Humaniter Internasional, Menjawab PertanyaanPertanyaan Anda, ICRC, 2004.

Haryomataram. 1999. "Uraian Singkat Tentang Armed Conflict,"

Paper presented at the Training on International Humanitarian Law and Human Rights, Banda Aceh.

Henckaerts, Jean Marie. "Studi (kajian) tentang Hukum Humaniter Internasional Kebiasaan," Jurnal Internasional Review of The Red Cross, volume 87, No. 857, March 2005. 
Khadduri, Majid. 2002. War and Peace in The Law of Islam (Perang dan Damai dalam Hukum Islam), Tarawang Press, Jakarta, 2002.

Kalshoven, Frits and Zegveld, Liesbeth. 2001. Constraints on the Waging of War: An Introduction to International Humanitarian Law, ICRC, Geneva

Kushartoyo (ed). 1999. Ketentuan-Ketentuan Lemabaga palang Merah Dalam Hukum Humaniter, Hukum Humaniter, Published in commemoration of 50 Year of Genewa Conventions 1949, Pusat Studi hukum Humaniter Fakultas Hukum Universitas Trisakti, Jakarta.

Kusumaatmadja, Mochtar. 1986. Konvensi-Konvensi Palang Merah 1949, Bina Cipta, Bandung.

Lachs, Manfred, and Swinarski Cristopher. 1984. Responsibility For The Development of Humanitarian Law, Studies and Essay on International Humanitarian Law and Red Cross Principles, Martinus Nijhoff Publishers, Leiden.

Rizki, Rudi M. 2005. Pokok-Pokok Hukum Hak Asasi Manusia Internasional, Seri Bahan Bacaan Kursus HAM untuk Pengacara X Tahun 2005, Materi : Hukum HAM Internasional, Lembaga Studi dan Advokasi Masyarakat, Elsam, Jakarta.

R, Kosirnik. 1997. The 1977 Protocol; A Landmark In The Development of International Humanitarian Law, ICRC, Oktober.

Suryohadiprojo, Sayidiman. 2008. Pengantar Ilmu Perang, Pustaka Intermasa, Jakarta.

Small, Melvin and Singer, David J, 1985. International War An Anthology and Study Guide, Dorsey Press Homewood, IL, USA.

Syamsudin, Otto Ishak and Abdul, Rahman Yakob. 2000. Catatan Pristiwa Kekerasan di Aceh Sepanjang Tahun 1999; Menjaring Hari Tampa Air Mata, Koalisi NGO HAM Aceh, Banda Aceh.

Rudy, T. May. 2001. Hukum Internasional 2, Refika Aditama, Bandung.

Syahrizal, Irwan. 2003. "Pengaturan Pelanggaran Berat Dalam Hukum Humaniter dan Penerapan Hukumnya di Indonesia,” Tesis, Universitas Padjadjaran, Bandung.

Wagiman. 2005. Wahyu. Hukum Humaniter Dan Hak Asasi Manusia, 
Seri Bahan Bacaan Kursus HAM untuk Pengacara X, Tahun 2005, Paper presented at ELSAM (Lembaga Studi dan Advokasi Masyarakat/Forum of Study and Community Advocate), Jakarta.

Wright, Quincy. 2004. Hukum Humaniter Sebelum Dikodifikasi, Bulletin ICRC.

\section{Websites}

http: / / www.hukumonline.com/klinik/detail/cl651/perlindunganhukum-bagi-tim-medis-di-wilayah-konflik.

http: / / www.tribunnews.com/internasional/ 2013/09/05/ dokterbedah-msf-ditemukan-tewas-di-aleppo-suriah http: / / nasional.kompas.com/read/2013/08/05/1452008/ JK.Penembakan.Dokter.PMI.di.Papua.Langgar.Hukum.Internasional 